\title{
OBSERVATIONS ON THE NESTING SITE AND BIOLOGY OF THE ARIZONA DAMP-WOOD TERMITE ZOOTERMOPSIS LATICEPS (BANKS) (HODOTERMITIDAE) $^{1}$
}

\author{
By W. L. Nutting \\ Department of Entomology, University of Arizona
}

The genus $Z$ ootermopsis includes the largest termites to be found in the United States. It contains but three species: angusticollis, the common damp-wood (or light-colored, rotten-wood) termite, ranging from southern British Columbia to northern Baja California and most abundant in the more humid coastal areas; nevadensis, the small (or dark-colored) damp-wood termite, roughly coextensive with the former but generally preferring cooler, drier areas and extending farther inland to western Montana; and laticeps, the Arizona dampwood termite, recorded from southeastern Arizona and southwestern New Mexico (Castle, 1934). Because of its large size and relatively easy availability in logs and stumps, angusticollis has become moderately well known and has proved a useful laboratory animal in a wide variety of studies (Snyder, 1956, I96I). To a lesser extent this is true for nevadensis. In contrast, no new biological information has appeared on laticeps since the early contributions by Townsend (1893), Banks (1906) and Banks and Snyder (I920). Although it is by far the largest, with soldiers 16 to $22 \mathrm{~mm}$. long and alates 25 to $30 \mathrm{~mm}$. over all, it has remained the least known of the three.

The following account summarizes the data on 27 collections of the alates of this spectacular termite made by various members, students and friends of the Department of Entomology at the University of Arizona, mainly during the last ten years. It also includes information gathered on four colonies which were located by the author after several years of sporadic but diligent searching. When it is realized that this termite stages its flights during the night and that it colonizes living, often very large, trees, its rarity becomes more understandable. It is thus not likely to be taken by the casual collector or without considerable effort.

Distribution. The collections of alates, made under lights and in light traps (both white and ultra violet) have considerably broadened the range of the species within the state of Arizona (Fig.

\footnotetext{
${ }^{1}$ Arizona Agricultural Experiment Station Journal, Article No. 967. Manuscript received by the editor February 19, 1965.
} 


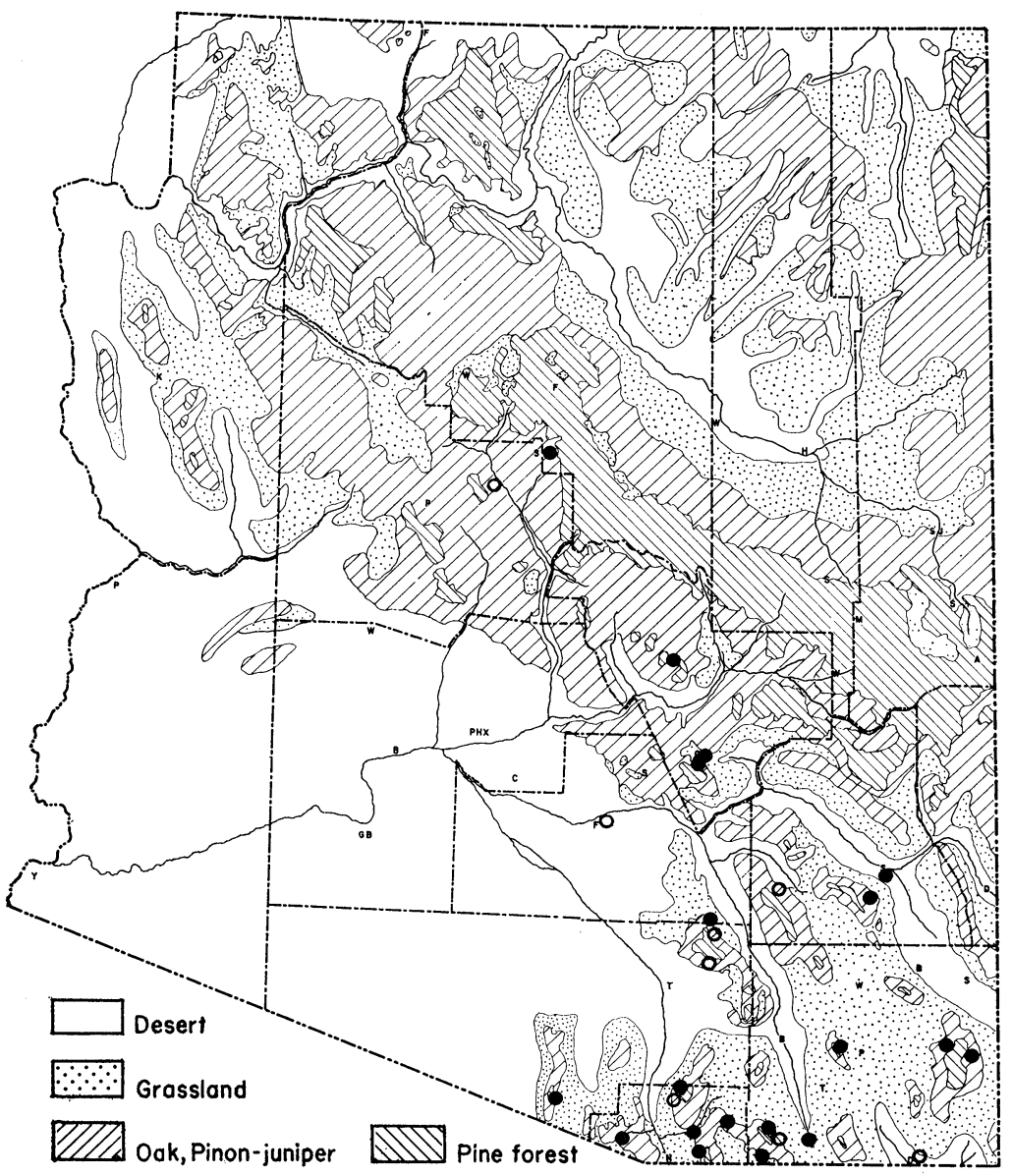

Figure 1. Map of the natural vegetation of Arizona, showing distribution of Zootermopsis laticeps: open circles, previous records; solid circles, new records.

I). Nineteen new localities are represented between Safford and the Chiricahua Mts. in the east and Sedona and the Baboquivari Mts. toward the center of the state. Except for Las Cruces, N. Mex., all previously published records fall within this area (Table I). Each collection has been made in the vicinity of a sizeable watercourse in canyons such as Ramsey in the Huachuca Mts., along more or less permanent streams as Sonoita Creek near Patagonia, in river bottoms 
as at Hereford or in heavily irrigated areas as in the Gila Valley at Safford. Although the altitudinal distribution ranges from I 500 feet in the creosote bush - salt brush desert around Florence to 5500 feet in oak - pine woodland along Workman Creek, all of these situations support at least thin stands of one or more large trees such as cottonwood, sycamore, ash, walnut and alder. Considering the intensity of light-trapping which has been done in Arizona, it does not seem likely that the range of laticeps will be extended much farther into the higher plateaus and mountains to the north or into the lesser ranges and desert to the west. However, it is highly probable that it might be found in the northwestern reaches of the Rio Grande, at least above and below Las Cruces, and south on both slopes of the Sierra Madre Occidental well into Sonora and Chihuahua.

Colonizing Flights. Lack of complete seasonal series of collections from any of the localities in Table I prevents a detailed characterization of the flight schedule of $Z$. laticeps. Alates appeared in a laboratory colony, maintained between 60 and $70^{\circ} \mathrm{F}$, during the first three weeks of June. Obviously it may be expected to fly from late June into early August over most of its range in Arizona, apparently with little regard for small differences in altitude. The records from Safford and Madera Canyon indicate that the seasonal flight pattern involves small groups of alates taking part in frequent, perhaps almost daily, flights over a period of six weeks or more. Since the highest monthly maximum temperature over most of this region is usually reached in late June or early July, and prior to any significant amount of rain (Sellers, 1960), it is suggested that high temperature may provide the major stimulus for initiating the flight period rather than the advent of the summer rains. Both Werner and Burger reported that no rain of any significance had fallen prior to the collections they had made in Madera Canyon and at Workman Creek (Table I).

Light and Weesner (1948, p. 55) took small numbers of alates between I and 4 A.M. and between I I P.M. and I $2: 45$ A.M. on two successive evenings in the Huachuca Mts. The complete absence of observations on any of the 27 flights recorded here, plus the fact that most collections were taken in light traps, further testifies to the fact that this termite does indeed fly during the night. The night at Peña Blanca (Table I) might be cited as typical of most of the lighttrapping ventures. The trap was run from shortly after sunset until sunrise and rather closely tended by four persons till midnight. No alates of any species of termite were seen; however, one alate of laticeps was taken from the trap the next morning. The only other data closely associated with any of the flights are the temperature and 


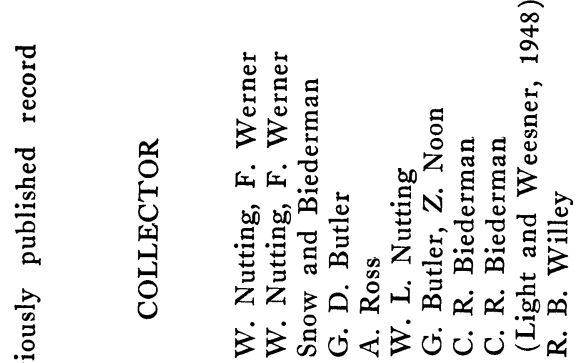

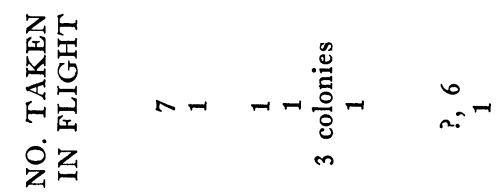

岕蓠

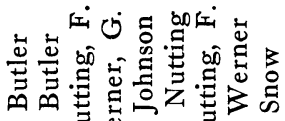

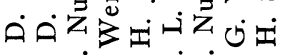

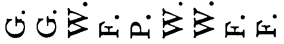

芒 离离

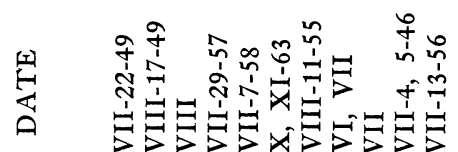

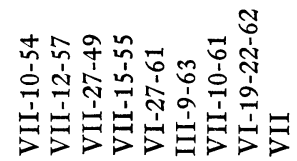

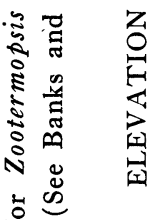

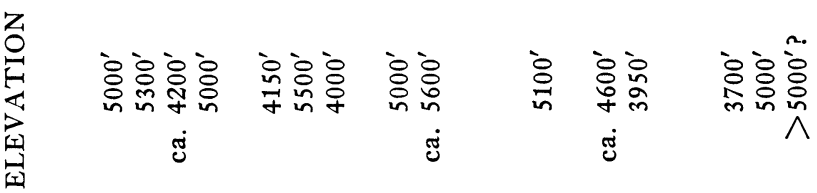

茎

वิ

盇

ซี

㺃

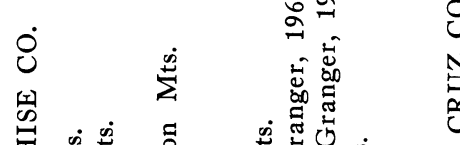

谽 范 
离

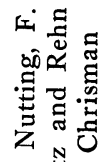

岕苔

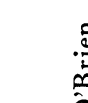

苟

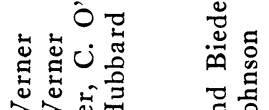
范密 ن் 庄远

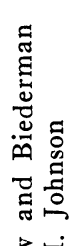

江.

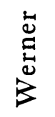

在

की

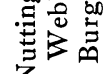

乙近

$\dot{\vec{\omega} \dot{\infty}}$
泀岕

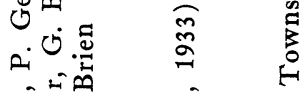

氖过

जिए हूँ

近可造

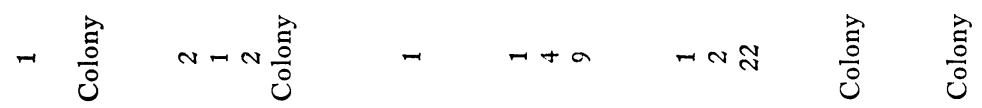

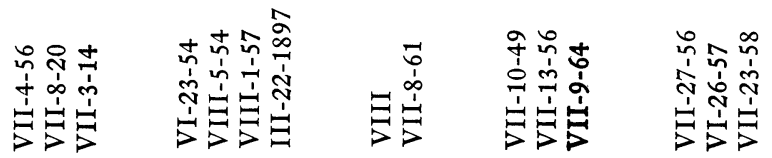

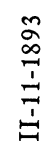

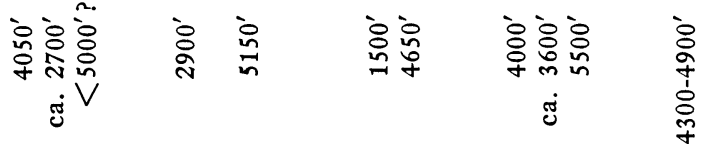

¿े

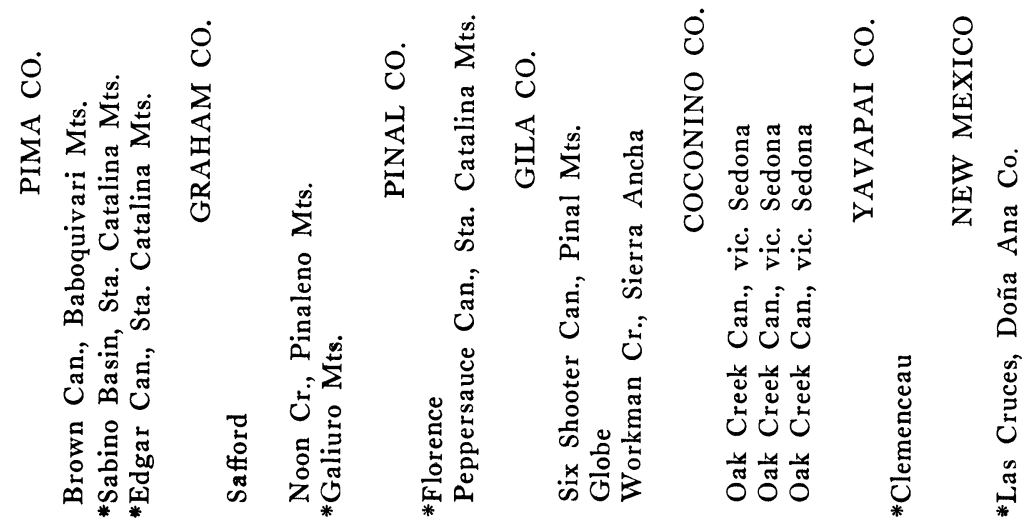




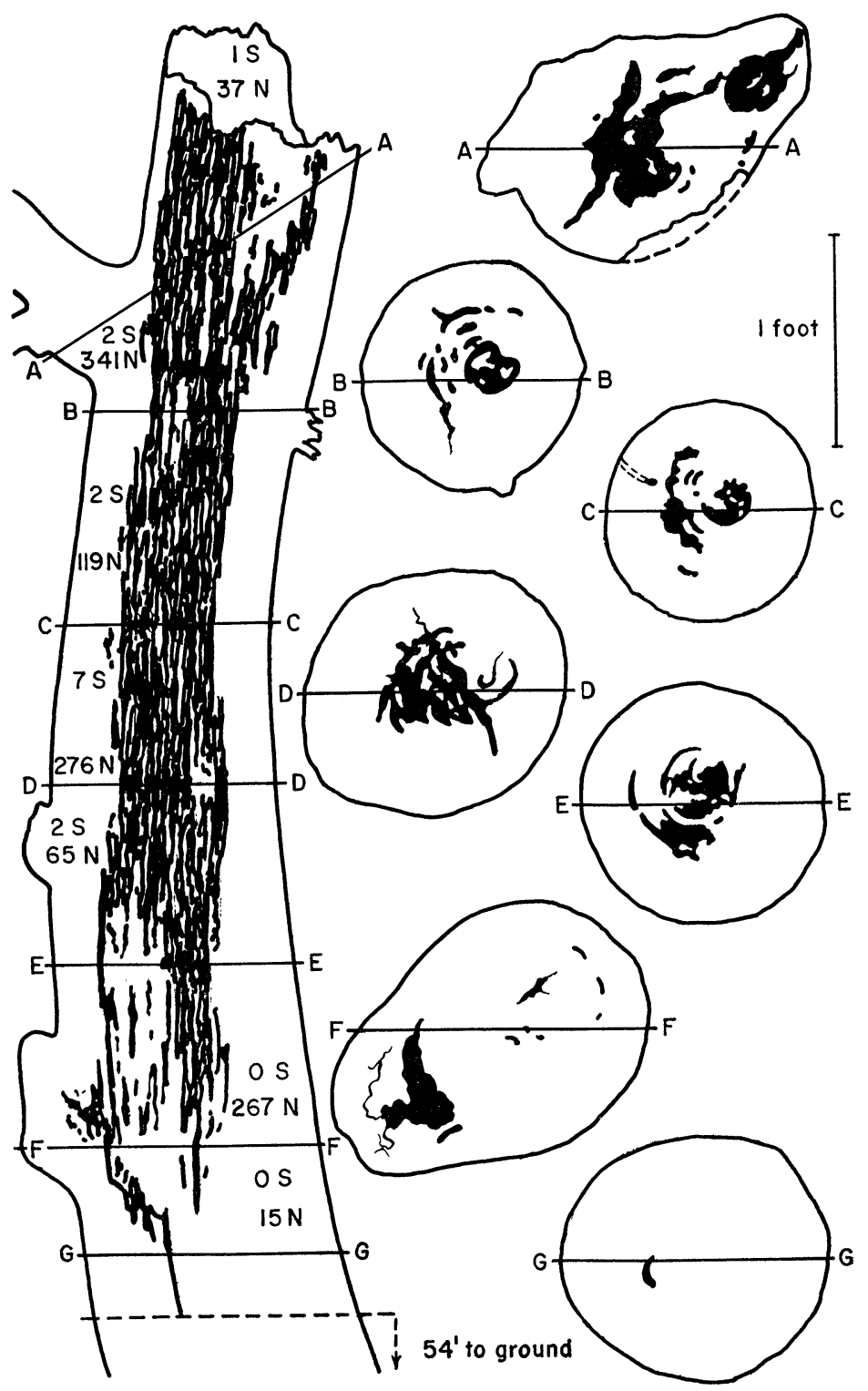

FIGURE 2 
relative humidity taken that evening at Peña Blanca $-92^{\circ}$ and $33 \%$ at 6:30 P.M., and $78^{\circ} \mathrm{F}$ and $44 \%$ at midnight, following a typical warm day with showers in the vicinity during late afternoon. This pattern of flight behavior is considerably more restricted than the evening flights of $Z$. angusticollis which have been reported during every month of the year (Castle, 1934). The more even temperatures in the coastal regions may be more conducive to a longer flight period than the seasonal extremes common to the desert Southwest.

Nesting site. Colonies have previously been reported in Fremont cottonwood (Populus Fremontii Wats.) (Townsend, I 893; Emerson, 1960, in litt.), alder (probably Alnus oblongifolia Torr.) and willow (Salix sp.) (Banks and Snyder, 1920). Cazier (1962) has mentioned exposing portions of colonies in burls on living sycamores (Platanus Wrightii Wats.) in Cave Creek Canyon between Portal and the Southwestern Research Station. Three colonies described in this report were found in willow (probably Salix Gooddingii Ball). Velvet ash (Fraxinus velutina Torr.), Arizona walnut [Juglans major (Torr.) Heller] and perhaps netleaf hackberry (Celtis reticulata Torr.) would also appear to provide suitable nesting sites for this termite. In each case colonies have been found in unhealthy trees or in those which have contained at least some dead portions.

The impregnability of the nesting site is dramatically illustrated by the first colony which was taken in a large Fremont cottonwood, on the flood plain 100 yards from Sonoita Creek and about two miles southwest of Patagonia. Fortunately the tree had been blown down, probably within six months or so, since it still bore many dried leaves. It measured at least 90 feet high and 6 feet in diameter at chest height. A few large nymphs of $\boldsymbol{Z}$. laticeps were first discovered in a burl formed around the base of a broken branch on one of the main limbs. This limb, at the trunk, was 18 inches in diameter 40 feet above the ground and had been broken off at 23.5 feet, apparently some years before. The wet, fibrous bark was easily stripped off and the limb was then sawed into two-foot lengths starting from the broken tip. It was later sawed into shorter lengths, tracings were made of the cross-sectional cuts (Fig. 2), and finally each section was carefully split and the entire colony removed. The colony was thus

Figure 2. Longitudinal section shows a reconstruction of the galleries of Zootermopsis laticeps in a cottonwood limb from Patagonia, Ariz. The actual numbers of nymphs (N) and soldiers (S) are indicated in each segment. Cross sections represent tracings of the galleries in the seven cuts $\mathrm{AA}$ to $\mathrm{GG}$. 
found to occupy the terminal six feet of the limb, ending approximately 54 feet above the ground.

Figure 2 shows the extent and character of what must have been several years' work by this well-established and vigorous colony. The configuration of the galleries indicates that the colony had originally extended farther up the limb and probably weakened it sufficiently to result in the break during a windstorm. The very large and extensive central galleries in the upper half of the colony were almost completely filled with hardened masses of fecal pellets, while the same situations were filled approximately 50 percent to within 18 inches of the lower end. It is apparent that this species often takes advantage of the softer spring wood in driving new galleries (note cross sections in Fig. 2), but through continued working these concentrically arranged chambers may be developed into cavities three or four inches in diameter and much more in length. The surface of the galleries has a coarse, velvety finish, characteristic of the other species of $Z$ ootermopsis. Cottonwood is fairly soft and light but very fibrous and tough. At the time the limb was cut, it was so wet from recent winter rains that water was squeezed out by the wedges used in splitting the sections. Although no other insects had penetrated the wood, the termites had followed shrinkage cracks in several places, particularly in the burls. The extremely tough and contorted grain of the burls seemed to be especially attractive. Four burls in the limb were extensively worked and each contained tunnels to the outside which were plugged with fecal material. One other tunnel, just below section C-C (Fig. 2) was driven directly to the outside. These openings measured about $3 \times 5$ to $6 \mathrm{~mm}$. and were presumably used as exits for the alates and perhaps also for dumping fecal pellets. It is interesting to note that the galleries of $Z$. angusticollis are predominantly peripheral in logs and stumps and that long, slit-like openings are made for the escape of the alates (Castle, 1934).

Three other colonies were found in willows along the bank of the San Pedro River at Hereford. The second complete colony was taken from a living tree approximately 30 feet high and 12 inches in diameter at the base. Individuals of this colony were discovered in damp, fermenting wood at the base of a broken branch six inches in diameter and four feet above the ground. The tree was felled and handled in the same way as the limb from Patagonia. As shown in figure 3, the galleries extended about two feet below the crotch of the snag in a pattern similar to that in the cottonwood limb. Some large cerambycid larvae had attacked this region prior to the termites, for the latter had driven galleries through the damp and firmly packed 
TABLE 2. Composition of two colonies of Zootermopsis laticeps.

\begin{tabular}{|c|c|c|c|c|c|}
\hline & Pat & $\begin{array}{r}\text { NYMPH } \\
\text { gonia, Arizo }\end{array}$ & na; March, & & SOLDIERS \\
\hline no wing pads & pre-alates & small pads & pigmented & unpigmented & \\
\hline $\begin{array}{c}10-13 \mathrm{~mm} . \\
552\end{array}$ & $\begin{array}{c}10-12 \mathrm{~mm} . \\
200\end{array}$ & $\begin{array}{c}7-10 \mathrm{~mm} . \\
162\end{array}$ & 4-7 mm. & ca. $3 \mathrm{~mm}$. & 2 \\
\hline & Here & ord, Arizor & Novembe & 1963 & \\
\hline $\begin{array}{c}10-13 \mathrm{~mm} . \\
232\end{array}$ & $\begin{array}{c}7-10 \mathrm{~mm} \text {. } \\
200\end{array}$ & $\begin{array}{c}\text { 5-7 mm. } \\
431\end{array}$ & $\begin{array}{c}4-5 \mathrm{~mm} . \\
155\end{array}$ & $\begin{array}{c}\text { ca. } 3 \mathrm{~mm} . \\
40\end{array}$ & 26 \\
\hline
\end{tabular}

detritus in the larval burrows. The willow had also been invaded, apparently at the base of the broken branch, by a bracket-fungus [Fomes igniarius (L. ex. Fr.) Kickx., kindly identified by Paul D. Keener of the Dept. of Plant Pathology]. The termites had restricted their galleries entirely to the column of softer, fungus-infected wood extending below into the base of the tree. It is probable that the cottonwood limb from Patagonia had been completely invaded by such a fungus but that the lack of contrast with any uninfected wood caused this point to go unnoticed. Unidentified Basidiomycetes and several other fungi have been isolated from colonies of $Z$. angusticollis and later experiments indicated that fungi play an essential role in its natural diet (Hendee, I933, I935). Only one obvious tunnel to the outside was found one foot below the crotch, its opening (sealed) in a deep furrow of the bark.

A third colony was also located, but not taken, at Hereford in a medium-sized, three-trunked willow. Superficial galleries, containing a few large nymphs, were exposed by chopping into the partly healed stub of a branch three inches in diameter and three feet above the ground. The utility of a trail-laying mechanism (reported in $Z$. nevadensis: Stuart, 1961) may be envisioned in the existence of a colony inhabiting galleries as extensive and complex as those described above.

Founding of the colony. A single incipient colony was found in the stub of a broken branch three inches in diameter and six feet from the ground on another small willow at Hereford. The de-alated king and queen had carved out a cell approximately $5 \times 10 \times 25 \mathrm{~mm}$. in the sap-soaked, splintered wood at the base of the branch. The pair had probably flown between late June and early August, 1963, and by this date (Oct. 26) had produced a single nymph, three $\mathrm{mm}$. long. This colony was maintained in a room varying between $55^{\circ}$ and $70^{\circ} \mathrm{F}$ and six eggs were produced during early March, 1964, when observations had to be discontinued. 

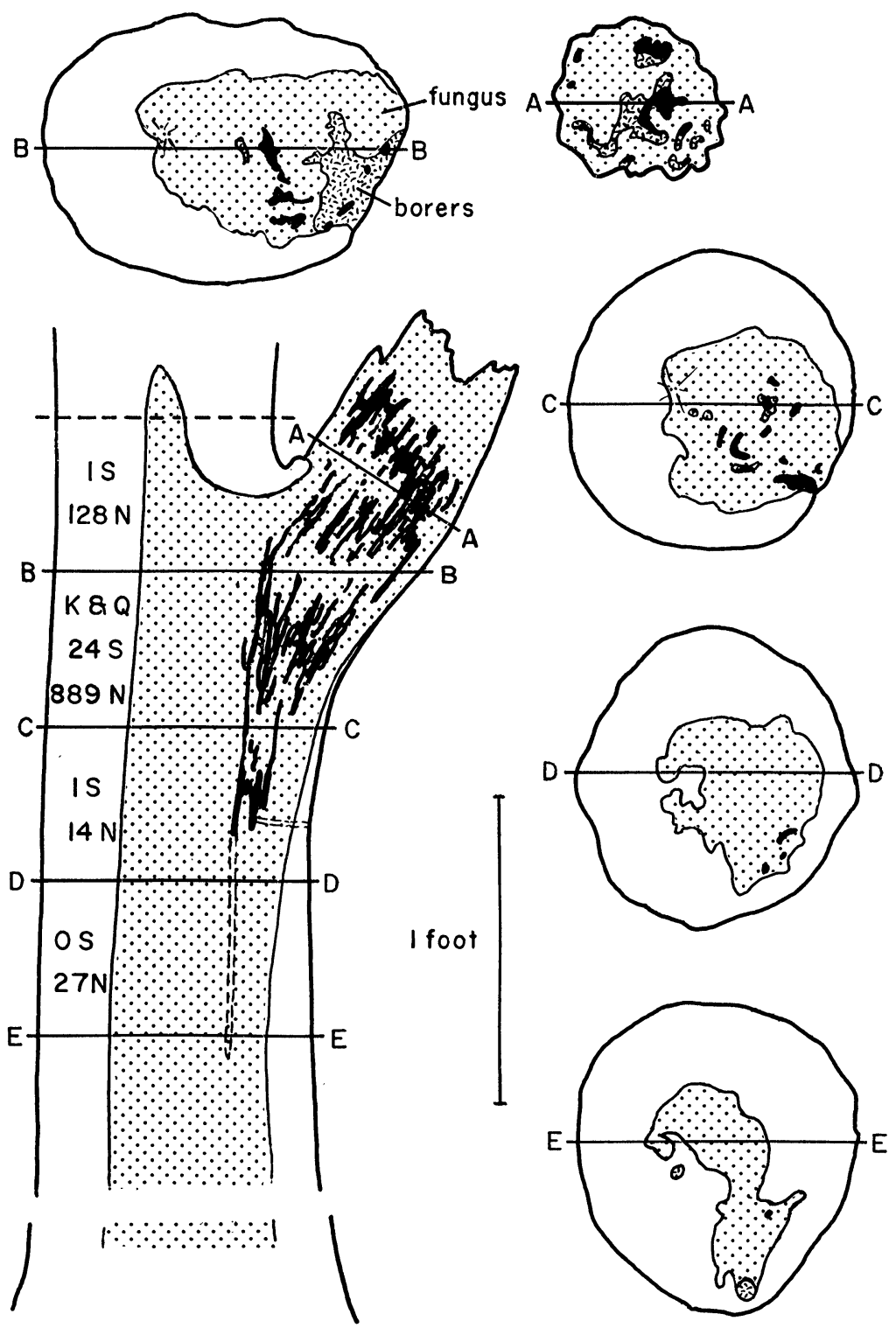

Figure 3 
This example, together with data accompanying the collections of other colonies, demonstrates what is probably the usual way in which this termite initiates its attacks on living trees. Several of the larger trees commonly suffer mutilations by windstorms, particularly cottonwood and willow. These open wounds may then provide focal points for the colonizing alates. This approach is reminiscent of the method by which Neotermes tectonae Damm. attacks living teak trees via dead branches, snags and wounds (Kalshoven, 1959). It remains to be determined, however, whether odors of freshly exposed wood or fermenting sap are actually attractive, and whether a fungous invasion is a prerequisite for the establishment of a colony.

Colony size and soldier-nymph ratio. Table 2 summarizes the composition of the two colonies which were investigated in detail. Since they were both established in laboratory nests, the individuals were quickly sorted into rough size-classes and counted; no attempt was made to determine the number of instars represented. The king and queen were not found in the Patagonia colony and no eggs were found in either colony. Although supplementary reproductives have been reported to be common in colonies of the other two species (Castle, 1934), none were found here. In the Patagonia colony, three months before the flight period, nymphs with wing pads of three different lengths were conspicuous: 200 pre-alates or nymphs in the penultimate instar and $\mathrm{I} 62$ with wing pads of short and intermediate lengths. The total number of alates eventually produced by this colony in the laboratory was not determined. The colony contained a total of 22 soldiers ( 2 small) and I 20 nymphs, with a soldier-nymph ratio of $\mathrm{I}$ to $5 \mathrm{I}$. In the colony from Hereford, three months after the flight period, none of the nymphs bore conspicuous wing pads. This colony contained 26 soldiers and 055 nymphs, making a soldiernymph ratio of $\mathrm{I}$ to $4 \mathrm{I}$. These counts are only one third to one-half the maximum colony size reported for $Z$. angusticollis, allhough the soldier-nymph ratio is about the same (Castle, 1934).

Insects associated with the colony. Among many miscellaneous insects and mites found within the galleries of the two large colonies, two deserve mention because the association may be more than casual. At least 19 small $(2-5 \mathrm{~mm}$.) cockroaches were found fairly evenly distributed through the galleries in the limb from Patagonia. Ashley

Figure 3. Longitudinal section shows a reconstruction of the galleries of Zootermopsis laticeps in the trunk of a living willow, Hereford, Ariz. The actual numbers of nymphs (N) and soldiers (S) are indicated in each segment. Cross sections represent tracings of the galleries in the five cuts $\mathrm{AA}$ to EE. 
B. Gurney (Insect Identification and Parasite Introduction Research Branch, U.S.D.A.) has informed me that the specimens appear to be nymphs of Compsodes schwarzi (Caudell). Practically nothing is known of this insect although Ball et al. (1942) reported that a winged male was taken in an ant nest in the Santa Rita Mountains.

Fifty-two syrphid larvae (4-I $5 \mathrm{~mm}$. long) were taken near the center of the colony from Hereford. Of several larger larvae which were set aside, one eventually pupated and developed into an adult. Willis W. Wirth (Insect Identification and Parasite Introduction Research Branch, U.S.D.A.) kindly identified the specimen as Tenthredomyia tridens (Loew). At least one member of this genus has been recorded "breeding" in the wounds of large trees (Wirth, 1964, in litt.). The presence of so many larvae, closely applied to the walls of the galleries containing the highest concentrations of the termites, is indeed puzzling. A few of the cockroaches and larvae were put into the large laboratory termite colonies, but it was impossible to observe anything beyond the fact that all three insects appeared to be indifferent to each other.

Additional collections of $Z$. laticeps are planned so that these associations can be studied further. In co-operation with Gordon B. Castle of Arizona State University, biological studies on laboratory colonies of the termite are also in progress.

\section{References Cited}

Ball, E. D., E. R. Tinkham, Robert Flock, and C. T. Vorhies.

1942. The grasshoppers and other Orthoptera of Arizona. Univ. Ariz. BANKs, N. Agric. Expt. Sta. Tech. Bull. No. 93, p. 266.

1906. Two new termites. Ent. News, 17:336-337.

BANKS, N., AND T. E. SNYDER.

1920. A revision of the nearctic termites (Banks) with notes on biology and geographic distribution (Snyder). U. S. Nat. Mus. Bull. Castle, G. B. No. 108,228 pp.

1934. The damp-wood termites of western United States, genus Zootermopsis. I. General biology and ecology, pp. 273-291. In Kofoid, C. A., et al. [eds.] Termites and Termite Control, 2nd CAZIER, M. A. Ed., Univ. Calif. Press, Berkeley.

1962. Personal communication.

EMERSON, A. E.

1933. A revision of the genera of fossil and recent Termopsinae

Emerson, A. E. (Isoptera), Univ. Calif. Publ. Ent., 6: p. 187.

1960. Personal communication. 
Granger, B. H.

1960. Will C. Barnes' Arizona Place Names, rev., Univ. Ariz. Press, Tucson, p. 38.

HendeE, E. C.

1933. The association of the termites, Kalotermes minor, Reticulitermes hesperus, and Zootermopsis angusticollis with fungi. Univ. Calif. Publ. Zool., $39: 111-134$.

Hendee, E. C.

1935. The role of fungi in the diet of the common dampwood termite, Zootermopsis angusticollis. Hilgardia, 9:499-525.

Kalshoven, L. G. E.

1959. Observations on the nests of initial colonies of Neotermes tectonae Damm. in teak trees. Bull. Union Internat. Étude Insectes Sociaux, $6: 231-242$.

Light, S. F., AND F. M. WEESNER.

1948. Biology of Arizona termites with emphasis on swarming. PanPacific Ent., 24: p. 55.

Sellers, W. D., Ed.

1960. Arizona Climate. Univ. Ariz. Press, Tucson, v + 60 pp., + climatological summaries.

SNYDER, T. E.

1956. Annotated, subject-heading bibliography of termites, 1350 B.C. to A.D. 1954. Smithsonian Misc. Coll., 130: iii +305 pp.

SNYDER, T. E.

1960. Supplement to the annotated, subject-heading bibliography of termites, 1955 to 1960 . Smithsonian Misc. Coll., 143: iii +137 pp.

Stuart, A. M.

1961. Mechanism of trail-laying in two species of termites. Nature (London), $189: 419$.

Townsend, C. H. T.

1893. Note on Termopsis angusticollis Hagen. Zoe, 4:139-141.

WIRTH, W. W.

1964. Personal communication. 

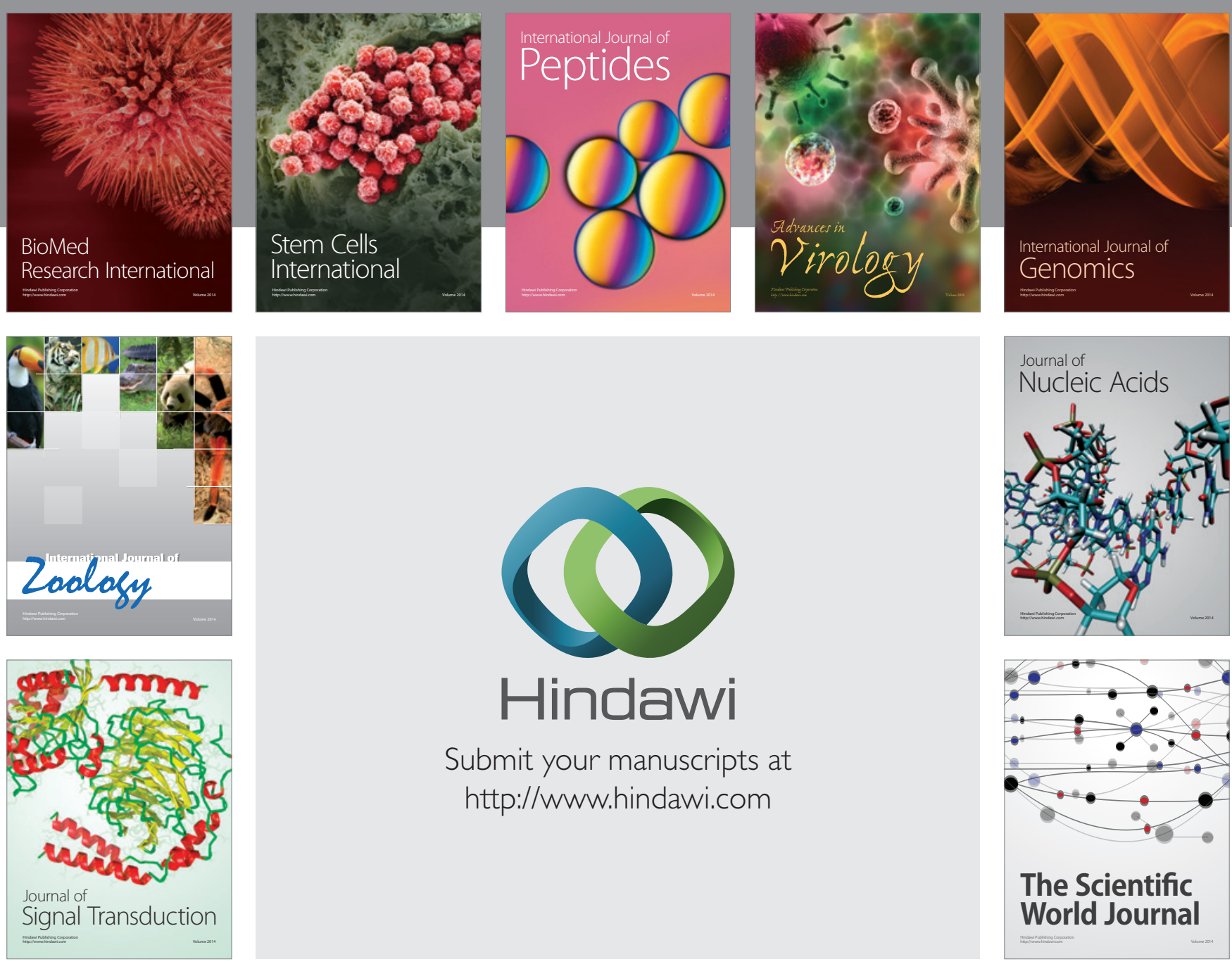

Submit your manuscripts at

http://www.hindawi.com
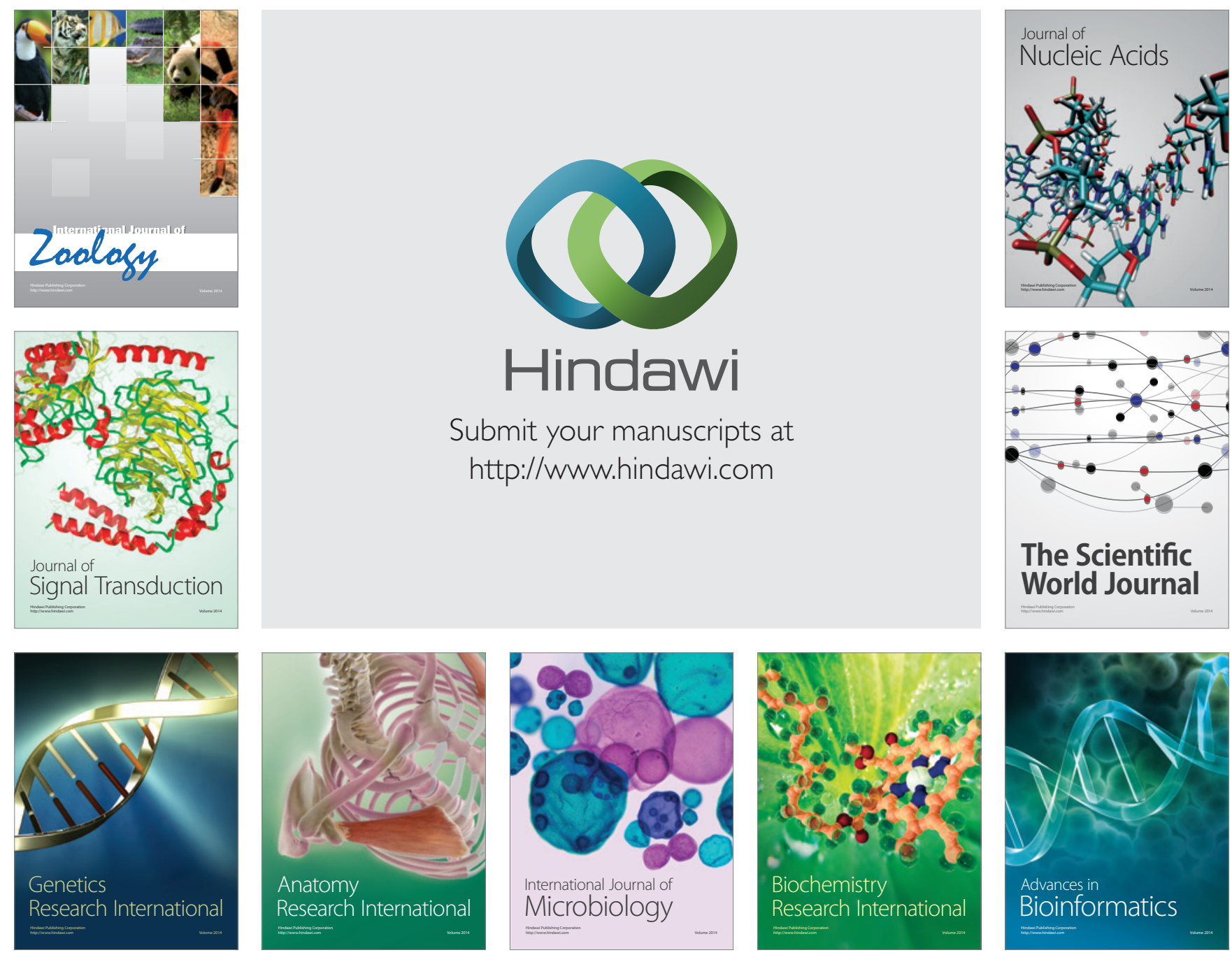

The Scientific World Journal
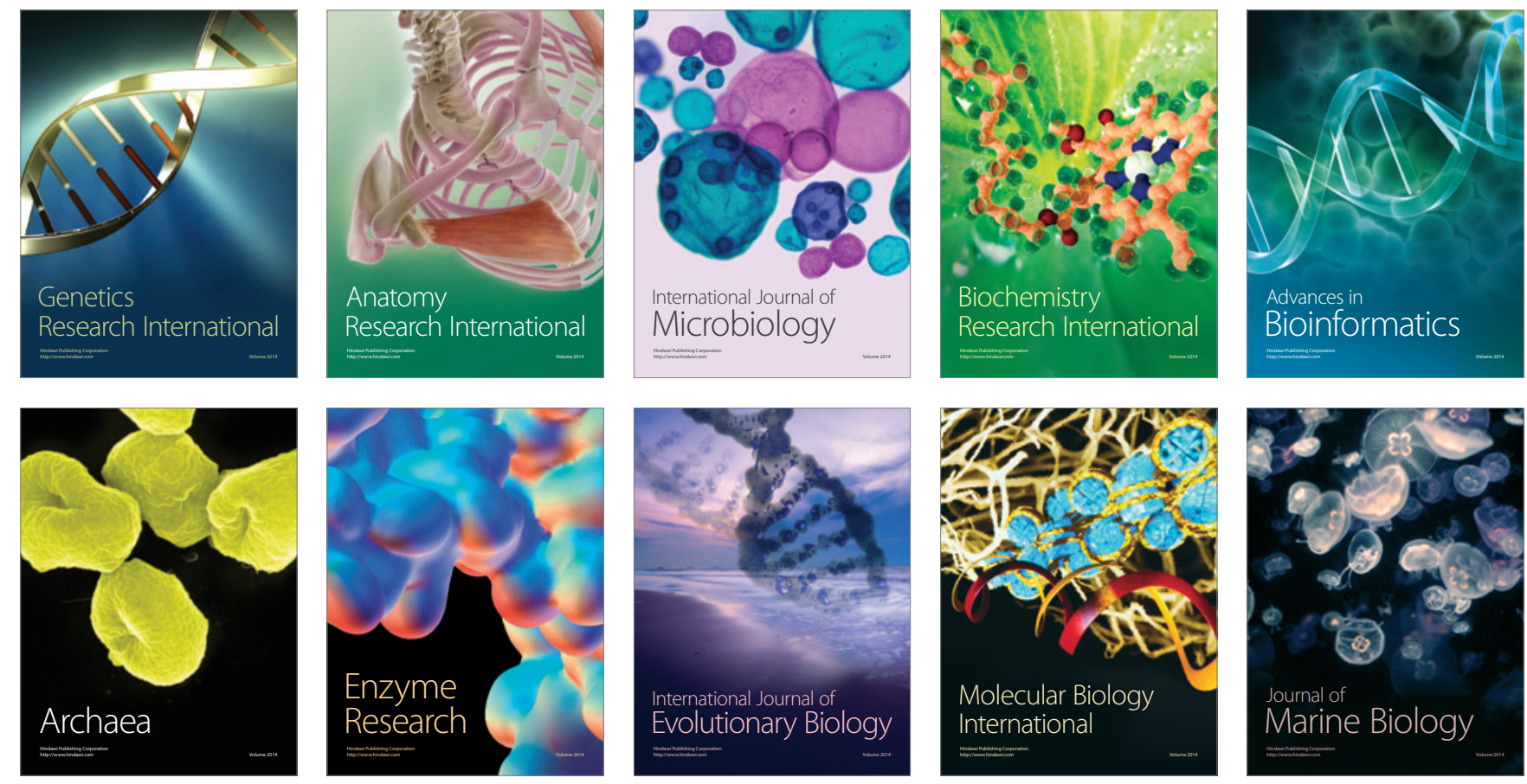